\title{
Iklan Media Instagram Mempengaruhi Keputusan Pembelian Produk Smartphone Merek Xiaomi di Kota Medan
}

\author{
Wirawan Candra Angkasa ${ }^{1}$, Ngajudin Nugroho ${ }^{1}$, Fauzi Akbar Maulana Hutabarat ${ }^{1, *}$, Supriyanto $^{2}$, Arwin $^{3}$ \\ ${ }^{1}$ Program Studi Manejemen Pemasaran, Politenik Cendana, Medan, Indonesia \\ ${ }^{2}$ Program Studi Administrasi Bisnis, Politeknik LP3I Medan, Medan, Indonesia \\ ${ }^{3}$ Program Studi Manajemen Perusahaan, PoliteknikCendana, Medan, Indonesia \\ Email: ${ }^{3, *}$ famhutabarat@gmail.com
}

\begin{abstract}
Abstrak-Penelitian ini bertujuan untuk mengetahui pengaruh iklan melalui media sosial Instagram terhadap keputusan pembelian pada smartphone Xiaomi. Penulis menggunakan metode kuantitatif asosiatif dengan teknik pengambilan sampel adalah sampling insidental, penelitian ini menggunakan SPSS untuk menganalisis pengaruh antara Iklan melalui sosial media Instagram dengan keputusan pembelian melalui kuisioner yang disebar kepada 40 orang responden yaitu masyarakat Kecamatan Medan Deli. Hasil dari penelitian ini adalah terdapat pengaruh antara Iklan melalui sosial media Instagram terhadap keputusan pembelian smartphone Xiaomi sebesar 40,7\% sedangkan sisanya 59,93\% dipengaruhi oleh faktor lain diluar penelitian ini.
\end{abstract}

Kata Kunci: Sosial Media; Keputusan Pembelian; Xiaomi; Iklan

Abstract-This study aims to determine the effect of advertising through Instagram social media on purchasing decisions on Xiaomi smartphones. The author uses an associative quantitative method with the sampling technique of incidental sampling, this study uses SPSS to analyze the effect of advertising through social media Instagram with purchasing decisions through questionnaires distributed to 40 respondents, namely the people of Medan Deli District. The results of this study are that there is an influence between advertising through Instagram social media on the purchasing decision of Xiaomi smartphones by $40.7 \%$ while the remaining $59.93 \%$ is influenced by other factors outside of this study.

Keywords: Social Media; Buying Decision; Xiaomi; Advertisement

\section{PENDAhuluan}

Saat ini di Indonesia terdapat banyak perusahaan elektronik ternama seperti Samsung, Apple, Lenovo, Oppo, Asus, Nokia, Blackberry, Advan, Xiaomi dan beberapa merek lainnya yang saling berkompetisi memperebutkan pangsa pasar dengan menawarkan harga yang bervariatif dan tentunya menggunakan strategi promosi yang mumpuni agar produk yang mereka jual lebih di kenal oleh masyarakat sehingga mereka mau membelinya. Promosi yang dilakukan pun beragam mulai dengan memberikan cashback, menggunakan brand ambassador dan membuat iklan yang unik di berbagai media cetak maupun online sehingga biaya yang dikeluarkan pun tidak sedikit. Salah satu smartphone yang saat ini tengah populer di masyarakat yaitu Xiaomi. Xiaomi merupakan smartphone asal Tiongkok yang memasuki pasar Indonesia pada tahun 2014 dengan produknya Xiaomi Redmi 1S dan ternyata smartphone Xiaomi diterima begitu baik oleh masyarakat karena menawarkan harga yang murah dengan kualitas produk yang mumpuni. Kini, memasuki tahun ketujuh berada di pasar Indonesia Xiaomi telah mengeluarkan berbagai macam tipe smartphone mereka diantaranya yaitu Xiaomi Redmi Note 7 , Xiaomi Redmi Note 7 pro, Xiaomi Redmi Note 8, Xiaomi Redmi Note 8 Pro, Xiaomi Redmi Note 9, Xiaomi Redmi Note 9 Pro, Xiaomi Redmi Note 10, Xiaomi Redmi Note 10 Pro dan masih banyak lagi. Guna memperkenalkan produk mereka, Xiaomi gencar melakukan promosi dengan memasang iklan di berbagai media, menggunakan artis top indonesia untuk menjadi brand ambassador mereka, dan menjadi sponsorhip berbagai acara di televisi. Berdasarkan data dari IDC (Internasional Data Corporation) di Indonesia pada kuartal ketiga 2018 terkait pasar smartphone di Indonesia, Samsung menduduki posisi pertama dan sepanjang juli hingga september 2018, Samsung menguasai 28\% pasar. Di posisi selanjutnya ada Xiaomi yang menguasai pasar 24\%, Oppo yang menguasai pasar 19\%, Vivo yang menguasai pasar $11 \%$, Advan yang menguasai pasar 5\%, dan $13 \%$ di kuasai oleh merek-merek lain. Diketahui bahwa perusahaan Xiaomi Indonesia telah mengeluarkan biaya yang tidak sedikit dalam mempromosikan produk smartphone mereka namun hanya bisa menguasai $24 \%$ pasar di Indonesia.

Dalam pelaksanaan penelitian ini, sebelumnya penulis melakukan pra penelitian dengan cara menyebarkan survei kepada masyarakat dikota Medan kecamatan Medan Deli pada bulan Februari. Berdasarkan hasil pra survei yang dilakukan oleh penulis, diperoleh 29 responden di dapatkan hasil : sebanyak 34.5\% masyarakat yang membeli smartphone Xiaomi dikarenakan Iklan di Instagram dan dari hasil survey tersebut diperoleh persentasi yang kecil, yaitu sebesar 34.5\%, maka dari fenomena yang ada peneliti tertarik untuk meneliti lebih jauh apakah benar adanya pengaruh Iklan terhadap keputusan pembelian smarthphone Xiaomi.

\section{KERANGKA TEORI}

\subsection{Advertising}

Periklanan American Marketing Association (AMA) mendefinisikan iklan sebagai semua bentuk bayaran untuk mempresentasikan dan mempromosikan ide barang atau jasa secara non perseonal oleh sponsor yang jelas. "Advertising is any paid form of nonpersonal presentation and promotion of ideas, goods, or services by an identified sponsor. 
Advertisers include not only business firms but also charitable, nonprofit, and government agencies"(Kotler \& Keller, 2016).

\subsection{Indikator Iklan}

Menurut Wibisono dalam (Hutagalung, 2016) indikator iklan adalah sebagai berikut:

a) Dapat menimbulkan perhatian

Iklan yang ditayangkan hendaknya dapat menarik perhatian pemirsa, oleh karena itu iklan harus dibuat dengan gambar yang menarik, tulisan dan kombinasi warna yang serasi dan mencolok, serta kata-kata yang mengandung janji, jaminan, serta menunjukkan kualitas produk yang diiklankan.

b) Menarik terbalik

Iklan yang diberikan kepada pemirsa harus dapat menimbulkan perasaan ingin tahu dari konsumen untuk mengetahui merek yang diiklankan lebih mendalam, dan biasanya dilakukan dengan menggunakan fitur iklan yang terkenal disertai dengan alur cerita yang menarik perhatian.

c) Dapat menimbulkan keinginan

Selain dapat menimbulkan perhatian dan menarik, sebuah iklan yang baik juga seharusnya dapat menimbulkan keinginan dalam diri konsumen untuk mencoba merek yang diiklankan. Dalam hal ini, penting bagi perusahaan untuk mengetahui motif dari pembelian konsumen, perusahaan dapat mengetahui apa yang menjadi keinginan dan kebutuhan konsumen.

d) Menghasilkan Suatu Tindakan

Keinginan yang kuat, maka konsumen akan mengambil tindakan untuk membeli merek yang diiklankan. Dan jika konsumen merasa puas dengan produk dari merek tersebut, maka konsumen akan mengkonsumsi atau melakukan pembelian ulang produk tersebut.

\subsection{Keputusan Pembelian}

Keputusan pembelian merupakan bagian dari perilaku konsumen yaitu studi tentang bagaimana individu, kelompok, dan organisasi memilih, membeli, menggunakan dan bagaimana barang, jasa, ide atau pengalaman untuk memuaskan kebutuhan dan keinginan mereka(Amstrong \& Kotler, 2015).

\subsection{Tahap Keputusan Pembelian}

Keputusan pembelian konsumen terdiri dari lima tahap yang dilakukan oleh seorang konsumen sebelum sampai pada keputusan pembelian dan selanjutnya pasca pembelian. terdiri dari, yaitu:

1. Problem Recognition (Pengenalan Masalah) Pada tahap ini konsumen mengetahui ada masalah atau kebutuhan yang harus diselelsaikan atau dipenuhi.

2. Information Research (Pencarian Informasi) Pada tahap ini konsumen mencari sebanyak-banyaknya informasi atas alternatif-alternatif pilihan akan barang atau jasa yang dibutuhkan dan diinginkan.

3. Information Research (Pencarian Informasi) Pada tahap ini konsumen mencari sebanyak-banyaknya informasi atas alternatif-alternatif pilihan akan barang atau jasa yang dibutuhkan dan diinginkan.

4. Purchase Decision (Keputusan Pembelian) Pada tahap ini konusmen telah menetapkan pilihan pada satu alternatif dan melakukan pembelian.

5. Postpurchase Decision (Perilaku Pasca Pembelian) Pada tahap setelah pembelian, konsumen akan mengalami level kepuasan dan ketidakpuasan(Amstrong \& Kotler, 2015).

\subsection{Indikator Keputusan Pembelian}

Keputusan pembelian adalah proses dimana konsumen melewati lima tahap yaitu pengenalan masalah, pencarian informasi, evaluasi alternatif, keputusan pembelian dan perilaku pasca pembelian. Terdapat 6 indikator keputusan pembelian, yaitu :

1. Pilihan Produk

Dalam hal ini perusahaan harus memusatkan perhatiannya kepada orang- orang yang berniat membeli sebuah produk serta alternatifnya yang mereka pertimbangkan. Konsumen dapat mengambil keputusan untuk memilih sebuah produk dengan pertimbangan: Keunggulan produk, yaitu tingkat kualitas diharapkan oleh konsumen pada produk yang dibutuhkan dari beragam pilihan yang ada. Manfaat produk, yaitu tingkat kegunaan yang dapat diperoleh konsumen pada tiap pilihan produk untuk memenuhi kebutuhannya. Pemilihan produk, yaitu pilihan konsumen pada produk yang akan dibelinya sesuai dengan kualitas yang diinginkan dan manfaat yang akan diperolehnya.

2. Pilihan Merek

Konsumen harus menjatuhkan pilihan pada merek apa yang akan dibeli. Dalam hal ini perusahaan harus mengetahui bagaimana cara konsumen menjatuhkan pilihan terhadap sebuah merek yaitu: Ketertarikan pada merek, yaitu ketertarikan pada citra merek yang sudah melekat pada produk yang dibutuhkan. Kebiasaan pada merek, yaitu konsumen memilih produk dengan merek tertentu, karena telah terbiasa dengan merek tersebut pada produk yang dibelinya. Kesesuaian harga, yaitu konsumen selalu mempertimbangkan harga yang sesuai dengan kualitas dan manfaat produk yang akan diperolehnya.

3. Pilihan Penyalur 
konsumen harus menentukan penyalur mana yang dipilih untuk membeli produk. Dalam hal ini konsumen memilih penyalur dapat dikarenakan faktor lokasi yang dekat, harga yang murah, tersedianya barang yang lengkap dan kenyamanan pada saat membeli. Kemudahan untuk mendapatkan produk yang diinginkan, konsumen akan merasa lebih nyaman jika lokasi pendistribusian produk mudah dijangkau dalam waktu yang singkat. Pelayanan yang diberikan, dengan pelayanan yang baik maka akan menimbulkan kenyamanan konsumen sehingga konsumen akan selalu memilih lokasi tersebut. Ketersediaan barang, kebutuhan dan keiinginan konsumen terhadap produk tidak dapat dipastikan kapan terjadi namun dengan ketersediaan barang yang memadai pada penyalur akan membuat konsumen memilih untuk melakukan pembelian di tempat tersebut.

4. Jumlah Pembelian

Konsumen dapat menentukan kuantitas barang yang akan dibeli. Dalam hal ini perusahaan harus mempersiapkan banyaknya produk yang sesuai dengan keinginan konsumen yang berbeda-beda. Karena konsumen akan menentukan: Keputusan jumlah pembelian, selain keputusan pada pilihan merek yang ditentukan konsumen, konsumen juga dapat menentukan kuantitas barang yang akan dibelinya. Keputusan pembelian untuk persediaan, dalam hal ini konsumen memilki produk selain untuk memenuhi kebutuhannya juga melakukan beberapa tindakan persiapan dengan sejumlah persdiaan produk yang mungkin dibutuhkannya pada saat mendatang.

5. Waktu pembelian

Pada saat konsumen menentukan waktu pembelian dapat berbeda-beda yaitu: Kesesuaian dengan kebutuhan, ketika mereasa butuh sesuatu dan merasa perlu melakukan pembelian. Keuntungan yang dirasakan, ketika konsumen membeli kebutuhannya akan suatu produk pada saat tertentu, maka pada saat itu konsumen akan merasakan keuntungan sesuai dengan kebutuhannya melalui produk yang dibelinya. Alasan pembelian, setiap produk memiliki alasan untuk memenuhi kebutuhan konsumen pada saat konsumen membutuhkannya.

6. Metode pembayaran

Konsumen dapat menetukan metode pembayaran yang akan digunakan pada saat transaksi pembelian. Konsumen mungkin akan menggunakan cara pembayaran: bayar tunai, cek, kartu kredit, kartu debit, kartu ATM, kredit melalui lembaga keuangan dan kredit melalui toko(Kotler \& Keller, 2016).

\section{METODOLOGI PENELITIAN}

\subsection{Metode Penelitian}

Dalam penelitian ini, penulis menggunakan metode penelitian kuantitatif. Menurut Sugiyono, Metode penelitian kuantitatif dapat diartikan sebagai metode penelitian yang berlandaskan pada filsafat positivisme, digunakan untuk meneliti pada populasi atau sampel tertentu, teknik pengambilan sampel pada umumnya dilakukan secara random, pengumpulan data menggunakan instrumen penelitian, analisis data bersifat kuantitatif/statistik dengan tujuan untuk menguji hipotesis yang telah ditetapkan(Yuliana, Jeffry, Akbar, Weny, \& Jackson, 2019). Metode penelitian yang digunakan oleh peneliti dalam penelitian ini adalah metode kuantitatif asosiatif. Penelitian asosiatif merupakan suatu rumusan masalah penelitian yang bersifat menyatakan hubungan antara dua variabel atau lebih, (Sugiyono, 2016). Teknik pengambilan sampel yang digunakan oleh penulis adalah sampling insidental. Menurut Sugiyono (Sugiyono, 2016) sampling insidental adalah teknik penentuan sampel berdasarkan kebetulan, yaitu siapa saja secara kebetulan/insidental bertemu dengan peneliti dapat digunakan sebagai sampel, bila dipandang orang yang kebetulan ditemui itu cocok dengan sumber data.

\subsection{Metode Analisa Data}

a. Koefisien Korelasi

Koefisien korelasi adalah tingkat keeratan hubungan antara variabel bebas dengan variabel terikat yang bernilai nol sampai satu. Apabila $\mathrm{r}$ mendekati satu maka dapat dikatakan bahwa memiliki hubungan yang sangat erat dan sebaliknya (Sutarno, Yenny, Supriyanto, Anggraini, \& Umar, 2019)

b. Koefisien Determinasi

Koefisien determinasi digunakan untuk mencari seberapa besar variasi variabel bebas dapat menjelaskan secara keseluruhan variasi variabel bebas.Koefisien determinasi mengukur seberapa besar pengaruh variabel bebas secara keseluruhan terhadap naik turunnya variasi nilai variabel. Koefisien determinasi (KD) adalah angka yang menyatakan atau digunakan untuk mengetahui kontribusi atau sumbangan yang diberikan oleh sebuah variabel atau lebih $\mathrm{X}$ (bebas) terhadap variabel Y (terikat) (Ivone, Wongnur, Arwin, Lisa, \& Ciamas, 2019)

c. Koefisien Linear Sederhana

Persamaan regresi liniear sederhana merupakan suatu model persamaan yang menggambarkan hubungan satu variabel bebas/ prediktor (X) dengan satu variabel tak bebas/ response (Y)(Ivone et al., 2019).

\subsection{Uji Hipotesis (Uji T)}

Pengujian hipotesis dilakukan dengan uji T. Uji t berguna untuk menguji pengaruh variabel bebas secara parsial atau sendiri- sendiri(Yuliana, Arwin, \& Pratiwi, 2020). Uji T digunakan ketika ukuran sampel kecil, dalam arti bahwa $\mathrm{n}<30$. a. Bila nilai sig. $<0,05$ berarti terdapat pengaruh yang signifikan variabel independen terhadap variabel dependen

b. Bila nig sig. > 0,05 berarti tidak terdapat pengaruh yang signifikan variabel independen terhadap variabel dependen. 


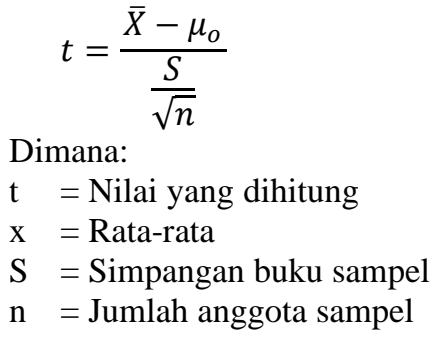

\section{HASIL DAN PEMBAHASAN}

\subsection{Hasil Uji Korelasi}

Tabel 1. Hasil Uji Korelasi

\section{Correlations}

\begin{tabular}{llll}
\hline & & Iklan & KeputusanPembelian \\
\hline Iklan & Pearson Correlation & 1 & $.633^{* *}$ \\
& Sig. (2-tailed) & & .000 \\
& $\mathrm{~N}$ & 40 & 40 \\
Keputusan Pembelian & Pearson Correlation & $.633^{* *}$ & 1 \\
& Sig. (2-tailed) & .000 & \\
& $\mathrm{~N}$ & 40 & 40 \\
\hline
\end{tabular}

**. Correlation is significant at the 0.01 level (2-tailed).

Dari hasil korelasi sederhana didapatkan besar $r$ sebesar 0,633. Hal ini menunjukkan bahwa hubungan Strategi promosi dan minat beli pelanggan adalah positif, kuat dan searah. Berarti semakin tinggi strategi promosi maka semakin tinggi pula keputusan pembelian. Hasil sig. (2-tailed) yang diperoleh sebesar 0,000<0,05. Artinya Ho ditolak.

\subsection{Hasil Koefisien Determinasi}

Tabel 2. Hasil Koefisien Determinasi

\begin{tabular}{|c|c|c|c|c|}
\hline \multicolumn{5}{|c|}{ Model Summary $^{\mathbf{b}}$} \\
\hline Model & $\mathrm{R}$ & R Square & $\begin{array}{l}\text { Adjusted R } \\
\text { Square }\end{array}$ & $\begin{array}{l}\text { Std. Error of the } \\
\text { Estimate }\end{array}$ \\
\hline 1 & $0.633^{\mathrm{a}}$ & 0.401 & 0.385 & 4.653 \\
\hline
\end{tabular}

$\mathrm{KD}=\mathrm{r}^{2} \times 100 \%$

$\mathrm{KD}=(0,633)^{2} \times 100 \%$

$\mathrm{KD}=40,07 \%$

Dari hasil koefisien determinasi diatas, menunjukkan pengaruh strategi iklan terhadap keputusan pembelian sebesar 40,07\% dan sisanya sebesar 59,93\% dipengaruhi faktor lain diluar penelitian ini.

\subsection{Hasil Regresi Linear Sederhana}

Tabel 3. Hasil Uji Regresi Linear Sederhana

\section{Coefficients $^{\mathrm{a}}$}

\begin{tabular}{|c|c|c|c|c|c|c|}
\hline \multirow{4}{*}{$\begin{array}{l}\text { Model } \\
1\end{array}$} & & Unstan & Coefficients & \multicolumn{3}{|c|}{$\begin{array}{l}\text { Standardized } \\
\text { Coefficients }\end{array}$} \\
\hline & & B & Std. Error & Beta & $\mathrm{t}$ & Sig. \\
\hline & (Constant) & 15.685 & 5.582 & & 2.810 & 0.008 \\
\hline & Iklan & 0.975 & 0.193 & 0.633 & 5.045 & 0.000 \\
\hline
\end{tabular}

a. Dependent Variable: KeputusanPembelian

Dari hasil tabel diatas dapat disimpulkan model regresi linear yaitu: $Y=15.685+0,975 X$. Artinya jika variabel bebas strategi promosi tidak mengalami peningkatan atau konstan, maka minat beli pelanggan sebesar 15.685 satuan dan jika variabel bebas strategi promosi mengalami peningkatan, maka minat beli pelanggan bertambah 0,975 satuan.

\subsection{Hasil Uji Hipotesis (Uji Z)}

Uji pengaruh variabel iklan terhadap keputusan pembelian Smartphone Xiaomi dapat dilihat melalui perhitungan: 


$$
\begin{aligned}
& Z=\frac{r}{\frac{1}{\sqrt{n-1}}} \\
& =\frac{0.633}{\frac{1}{\sqrt{40-1}}} \\
& =\frac{0.633}{\frac{1}{\sqrt{39}}} \\
& =3.953
\end{aligned}
$$

Berdasarkan hasil perhitungan uji Z diatas dihasilkan nilai $\mathrm{Z}$ statistik adalah sebesar 3.953 dan berdasarkan tabel distribusi normal standar diperoleh nilai Z tabel adalah sebesar 1,96. Dimana Z statistik > Z tabel (3.953 > 1,96), maka Ho ditolak dan Ha diterima yang berarti ada pengaruh iklan terhadap minat keputusan pembelian Smartphone Xiaomi. Pengujian hipotesis dilakukan dengan uji Z. perumusan hipotesis penelitian sebagai berikut:

Ho; Tidak ada pengaruh iklan terhadap keputusan pembelian Smartphone Xiaomi.

Ha; Adanya pengaruh iklan terhadap keputusan pembelian Smartphone Xiaomi.

\section{KESIMPULAN}

Berdasarkan hasil uji z menunjukan Ho ditolak dan Ha diterima yang berarti ada pengaruh iklan terhadap keputusan pembelian Smartphone Xiaomi. Berdasarkan hasil uji korelasi sederhana didapatkan besar r sebesar 0,633 yang berarti hubungan iklan dan keputusan pembelian memiliki korelasi positif, kuat dan searah. Berdasarkan hasil koefisien determinasi, menunjukkan pengaruh iklan terhadap keputusan pembelian adalah sebesar 40,07\% dan sisanya sebesar $59,93 \%$ dipengaruhi faktor lain diluar penelitian ini. Berdasarkan hasil regresi linear sederhana dapat disimpulkan $\mathrm{Y}=$ $15.685+0,975 \mathrm{X}$, menunjukan nilai konstanta adalah 6,256 yang berarti apabila tidak terjadi peningkatan pada strategi promosi, maka minat beli pelanggan adalah sebesar 15.685. Koefisien dari variabel X (Iklan) adalah sebesar 0.975 yang berarti setiap bertambah atau meningkat 1 satuan strategi promosi maka dapat meningkatkan minat beli pelanggan sebesar 0,975 kali. Berdasarkan hasil uji data yang dilakukan oleh peneliti, iklan berpengaruh positif terhadap keputusan pembelian, pengaruhnya sebesar $40.07 \%$ terhadap keputusan pembelian dan memiliki hubungan korelasi 0.633 . hubungan antara iklan terhadap keputusan pembelian.

\section{DAFTAR PUSTAKA}

Amstrong, \& Kotler, P. (2015). Marketing In Introduction Prenticell Hall. London: Pearson Education, Inc.

Hutagalung, A. (2016). Pengaruh Iklan dan Harga terhadap Keputusan Pembelian pembelian mie instan merek supermie pada Mahasiswa Fakultas Ekonomi \& Bisnis Universitas Medan Area.

Ivone, I., Wongnur, T., Arwin, A., Lisa, L., \& Ciamas, S. E. (2019). Pengaruh Biaya Promosi Terhadap Peningkatan Jumlah Murid di Sempoa Sip Sumut Dan Aceh. Jurnal Ilmiah Simantek, 3(2).

Kotler, P., \& Keller, K. L. (2016). Marketing Management. London: Pearson Education, Inc.

Sugiyono. (2016). Metode Penelitian Kuantitatif, Kualitatif dan $R \& D$. Bandung: PT Alfabet.

Sutarno, S., Yenny, Y., Supriyanto, S., Anggraini, D., \& Umar, Z. (2019). Pengaruh Komunikasi Terhadap Kinerja Karyawan CV. Bintang Jaya Abadi. JURNAL ILMIAH MAKSITEK, 4(2).

Yuliana, Y., Arwin, A., \& Pratiwi, J. D. (2020). Dampak Gaji dan Gaya KepemimpinanTerhadap Kepuasan Kerja Karyawan (Studi Kasus Pada PT Cipta Mandiri Agung Jaya). BISMA Cendekia, 1(September), 35-40.

Yuliana, Y., Jeffry, J., Akbar, A., Weny, W., \& Jackson, M. (2019). Pengaruh Motivasi Terhadap Peningkatan Kinerja Karyawan PT. Bank Central Asia Cabang Golden Trade Medan. Jurnal Ilmiah Simantek, 3(1). 